\title{
Synthesis of Fluorine-18 Labeled GABA Uptake Inhibitors
}

\author{
MICHAEL R. KILBOURN, ${ }^{1 *}$ MICHAEL R. PAVIA ${ }^{2}$ and VLAD E. GREGOR ${ }^{2}$ \\ 'Division of Nuclear Medicine, University of Michigan, Ann Arbor and ${ }^{2}$ Parke-Davis Pharmaceutical \\ Research Division, Warner-Lambert Co., Ann Arbor, MI 48105, U.S.A.
}

(Received 5 March 1990)

\begin{abstract}
The first syntheses of fluorine-18 labeled inhibitors of GABA reuptake $[(R, S)-1-\{2-\{4-$ $\left[{ }^{18}\right.$ F]fluorophenyl\}phenyl $\}$ methoxyethyl]piperidine-3-carboxylic acid, (R,S)-1-\{2-(4- $\left.{ }^{18} \mathrm{~F}\right]$ fluorophenyl)(4fluorophenyl)methoxyethyl\}piperidine-3-carboxylic acid, and (R,S)-1- $\left\{2-\left\{\left(4-\left[{ }^{18} \mathrm{~F}\right]\right.\right.\right.$ triffuoromethyl)phenyl $\}$ $\{(4-$ trifluoromethyl)phenyl $\}$-methoxyethyllpiperidine-3-carboxylic acid] are described. These $N$-substituted nipecotic acid derivatives were prepared in no-carricr-added form by the condensation of the appropriately substituted $\left[{ }^{18} \mathrm{~F}\right]$ benzhydryl chlorides (prepared in three steps from $\left[{ }^{18} \mathrm{~F}\right]$ fluoride ion) with $N$-(2-hydroxyethyl)nipecotic acid ethyl ester, followed by ester hydrolysis. Overall radiochemical yields were $17-28 \%$ (corrected, 150 min synthesis time). A simple new method for synthesis of a $\left[{ }^{18} \mathrm{~F}\right]$ trifluoromethyl group by the nucleophilic substitution of a bromodifluoromethyl substituent has also been developed.
\end{abstract}

\section{Introduction}

Gamma aminobutyric acid (GABA) is an inhibitory amino acid neurotransmitter involved in the control of neuronal activity in the brain (Enna, 1980; Krogsgaard-Larsen et al., 1987). Dysfunctions of the GABA system have been implicated in a wide variety of neurological disorders, and are of particular interest in studies of epilepsy and other seizure disorders. In vivo approaches to the study of the GABA system in man using positron emission tomography (PET) have centered on the preparation and application of radiolabeled ligands known to bind to the GABA/benzodiazepine receptor complex (Maziere et al., 1980, 1984; Frost et al., 1986).

An alternative approach to the study of the role of degeneration of the GABA neurotransmitter pathway in disease would be development of in vivo markers of the presynaptic GABA-ergic neurons. Reasonable approaches are the development of radiolabeled synthetic precursors to GABA formation; radiolabeled inhibitors of the enzymes involved in GABA production (e.g. glutamic acid decarboxylase, GAD); or radiolabeled inhibitors of the presynaptic GABA reuptake system. This last option is particularly appealing due to the interest in developing drugs

*All correspondence should be addressed to: Michael R. Kilbourn, Ph.D., Cyclotron/PET Facility, 3480 Kresge III, University of Michigan, Ann Arbor, MI 48109, U.S.A. that block this process for use in treatment of epilepsy (Krogsgaard-Larsen et al., 1987). The mechanisms of GABA uptake are not well understood, and there is relatively little data regarding in vivo pharmacokinetics and specificity of GABA uptake inhibitors. We describe here the first synthesis of novel ${ }^{18} \mathrm{~F}$ labeled GABA uptake inhibitors (Fig. 1: Pavia, 1988; Taylor and Vartanian, 1989) as potential radioligands for studying the GABA system by in vivo methods (ex vivo tissue counting, in vivo autoradiography, and PET).

\section{Experimental}

\section{Materials}

The following were obtained from Aldrich Chemical Co. and used without further purification: terephthaldehyde, diethylaminosulfur trifluoride (DAST), 4-bromobenzotrifluoride, Kryptofix 2.2.2, lithium aluminum hydride (1 $\mathrm{M}$ in diethyl ether). The quaternary ammonium resin was prepared as previously described (Mulholland et al. 1989b). High specific activity $(50,000 \mathrm{Ci} / \mathrm{mmol}) \quad\left[{ }^{18} \mathrm{~F}\right]$ fluoride ion was produced by proton irradiation of $\left[{ }^{18} \mathrm{O}\right]$ water held in an all silver cyclotron target as previously described (Mulholland et al., 1989a). Preparations of 4- $\left[{ }^{18} \mathrm{~F}\right]$ fluorobenzhydryl chloride (11) (Haka et al., 1989) and 4-[ ${ }^{18}$ F]fluoro-4'-fluorobenzhydryl chloride (12) (Haka and Kilbourn, 1990) were according to literature methods. 


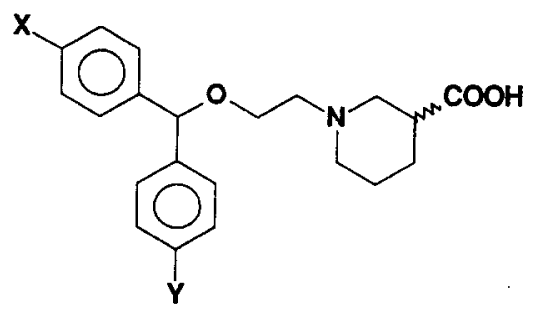

$$
\begin{aligned}
& 1 X=H, Y={ }^{18} F \\
& 2 X=F, Y={ }^{18} F \\
& 3 X=C F_{3}, Y=C F_{2}{ }^{18} \mathrm{~F}
\end{aligned}
$$

Fig. 1. Fluorine-18 labeled inhibitors of GABA reuptake

\section{Methods}

Melting points were determined on a ThomasHonver capillary melting point apparatus and are uncorrected. NMR spectra were recorded with a Varian EM-390 spectrometer using TMS as internal reference. Infrared spectra were recorded with a Nicolet XS-20 FT-IR spectrometer using KBr plates. Thin layer chromatography was done using plasticbacked silica gel plates (Merck) and the following systems: System A, silica gel, 5/2 pentane/diethyl ether; System B, silica gel, $7 / 3$ hexane/ethylacetate; System C, 7/2.5/0.5 toluene/isopropanol/acetic acid. HPLC was done using a Phenomenex $\mathrm{C} 18 \quad 10 \mu$ $0.45 \times 10 \mathrm{~cm}$ column fitted with u.v. $(263 \mathrm{~nm})$ and radioactivity detectors, and a mobile phase of $60 / 40 / 3$ acetonitrile/ $0.065 \mathrm{M}$ aqueous ammonium acetate/ tetrahydrofuran (flow rate $0.5 \mathrm{~mL} / \mathrm{min}$ ).

All radiochemical yields are corrected for decay of ${ }^{18} \mathrm{~F}\left(t_{1 / 2}=110 \mathrm{~min}\right)$.

4-(Difluoromethyl)benzaldehyde (5). Terephthaldehyde (4: $38 \mathrm{~g}, 0.28 \mathrm{~mol})$ was dissolved in dichloromethane $(350 \mathrm{~mL})$, a nitrogen atmosphere introduced, and the mixture cooled to $-10^{\circ} \mathrm{C}$. A solution of DAST $(38 \mathrm{~g}, 0.24 \mathrm{~mol})$ in dichloromethane $(50 \mathrm{~mL})$ was added dropwise over $1 \mathrm{~h}$. The reaction was stirred for 4 days at room temperature, quenched very carefully by slow $(30 \mathrm{~min})$ addition of water $(25 \mathrm{~mL})$, and neutralized with saturated aqueous $\mathrm{NaHCO}_{3}$. The aqueous layer was repeatedly extracted with $\mathrm{CH}_{2} \mathrm{Cl}_{2}$, and the extracts dried $\left(\mathrm{MgSO}_{4}\right)$, filtered through silica and evaporated in vacuo at temperature $<10^{\circ} \mathrm{C}$. The remaining oil $(36 \mathrm{~g})$ was distilled $\left(113-115^{\circ} \mathrm{C}, 20\right.$ torr) to give $19.9 \mathrm{~g}$ ( $54 \%$ yield) of the desired aldehyde 5 , which was used in the next step without further purification. ${ }^{1} \mathrm{H}-\mathrm{NMR}\left(\mathrm{CDCl}_{3}\right) \delta 9.8$ (bs, $\left.1 \mathrm{H}, \mathrm{CHO}\right), 7.65-7.35$ (dd, $4 \mathrm{H}, \mathrm{ArH}), 6.68\left(\mathrm{t}, 1 \mathrm{H}, \mathrm{J}=55.9 \mathrm{~Hz}, \mathrm{CHF}_{2}\right.$ ).

$(R, S)$ - $\alpha$-[4-(Difluoromethyl)phenyl]-4-(trifluoromethyl)benzenemethanol 6. 4 Bromobenzotrifluoride $(2.25 \mathrm{~g}, 10 \mathrm{mmol})$ was added dropwise to a mixture of magnesium metal $(0.24 \mathrm{~g}, 10 \mathrm{mmol})$ in diethyl ether $(30 \mathrm{~mL})$. The reaction was initiated (manual crushing of $\mathrm{Mg}$, addition of iodine crystal) and the 4-bromobenzotrifluoride added at a rate sufficient to maintain reflux. When the addition was complete, the reaction was refluxed for an additional $45 \mathrm{~min}$ and then cooled to $0{ }^{\circ} \mathrm{C}$. Approximately one-fifth of this Grignard reagent was then added to a solution of $5(0.31 \mathrm{~g}$, $2 \mathrm{mmol})$ dissolved in cold ether $(2 \mathrm{~mL}, 0 \mathrm{C})$. The reaction was monitored by TLC (silica, 10\% EtOAc/hexane) which indicated incomplete consumption of aldehyde 5. A small additional amount of Grignard reagent was added and the reaction then judged complete by TLC. The mixture was diluted with ether and washed with saturated $\mathrm{NH}_{4} \mathrm{Cl}$ solution. The organic layer was dried $\left(\mathrm{MgSO}_{4}\right)$, filtered, and evaporated in vacuo. Purification by flash column chromatography (silica, 15\% EtOAc/hexane) and crystallization from hexane afforded $0.48 \mathrm{~g}$ $\left(80 \%\right.$ yield) of the product $6 ;$ m.p. $81-82^{\circ} \mathrm{C} ;{ }^{1} \mathrm{H}-\mathrm{NMR}$ $\left(\mathrm{CDCl}_{3}\right) \delta 7.65-7.45(\mathrm{~m}, 8 \mathrm{H}, \mathrm{ArH}), 6.65(\mathrm{t}, 1 \mathrm{H}$, $\left.\mathrm{J}=56.6 \mathrm{~Hz}, \mathrm{CHF}_{2}\right), 5.94(\mathrm{~s}, 1 \mathrm{H}, \mathrm{CHOH}), 2.10(\mathrm{bs}$, $1 \mathrm{H}, \mathrm{OH})$; MS $302\left(\mathrm{M}^{+}\right), 301\left(\mathrm{M}^{+}-1\right)$; i.r. $\left(\mathrm{cm}^{-1}\right)$ 3350,1619 , 1425, 1376; Anal. Calcd for $\mathrm{C}_{15} \mathrm{H}_{11} \mathrm{~F}_{5} \mathrm{O}$ : C, 59.61; H, 3.69. Found; C, 59.82; H, 3.64.

[4-(Difluoromethyl)phenyl]-[4-(trifluoromethyl)phenyllmethanone 7 . The benzhydrol $6(0.6 \mathrm{~g}, 2 \mathrm{mmol})$ was dissolved in acetone $(30 \mathrm{~mL})$ and cooled to 0 " $\mathrm{C}$. Jones reagent $\left(\mathrm{CrO}_{3} / \mathrm{H}_{2} \mathrm{SO}_{4} / \mathrm{H}_{2} \mathrm{O}\right)$ was added dropwise until an orange color persisted. The reaction was stirred an additional $5 \mathrm{~min}$ then quenched by addition of methanol. The product was poured into ether, the solid removed, and the organic layer evaporated in vacuo. The residue was again taken up in ether, decanted from solids, and evaporated. The white solid oblained was recrystallized from hexane to afford $0.44 \mathrm{~g}(74 \%)$ of the ketone $7 ; \mathrm{m} . \mathrm{p}$. $131-131.5 \mathrm{C} ;{ }^{1} \mathrm{H}-\mathrm{NMR}\left(\mathrm{CDCl}_{3}\right) \delta 7.92-7.65(\mathrm{~m}, 8 \mathrm{H}$, ArH), $6.74\left(\mathrm{t}, 1 \mathrm{H}, \mathrm{J}=56 \mathrm{~Hz}, \mathrm{CHF}_{2}\right) ; \mathrm{MS} 300\left(\mathrm{M}^{+}\right)$, $281\left(\mathrm{M}^{+}\right.$-19); i.r. $\left(\mathrm{cm}^{-1}\right) 1653,1615,1578,1511,1409$, 1331; Anal. Calcd for $\mathrm{C}_{15} \mathrm{H}_{9} \mathrm{~F}_{5} \mathrm{O}: \mathrm{C}, 60.01 ; \mathrm{H}, 3.02$. Found: C, 60.01; H, 2.98.

[4-(Bromodifluoromethyl)phenyl]-[(4-trifluoromethyl) phenylmethanone 8 . The benzophenone 7 $(3.0 \mathrm{~g}, 10 \mathrm{mmol})$ was suspended in $\mathrm{CCl}_{4}(40 \mathrm{~mL})$ and to this added anhydrous $\mathrm{K}_{2} \mathrm{CO}_{3}(6.9 \mathrm{~g}, 50 \mathrm{mmol})$ and then $\mathrm{Br}_{2}(1.76 \mathrm{~g}, 11 \mathrm{mmol})$. The reaction mixture was placed under an atmosphere of $\mathrm{N}_{2}$ and illuminated with a $275 \mathrm{~W}$ sunlamp which raised the temperature to $45^{\circ} \mathrm{C}$. After $24 \mathrm{~h}$ additional $\mathrm{Br}_{2}(1.76 \mathrm{~g}, 10 \mathrm{mmol})$ was added and the reaction continued for a total of $60 \mathrm{~h}$, at which time TLC (silica, 5\% EtOAC/hexane) showed complete conversion. The reaction mixture was cooled, diluted with $\mathrm{CH}_{2} \mathrm{Cl}_{2}$, and then washed with saturated aqueous soldium silfite and sodium chloride solutions. The organic layer was dried $\left(\mathrm{MgSO}_{4}\right)$ and evaporated to give a solid which was dissolved in 1:1 ethyl acetate/hexane and passed through a short column of silica. The solvent was evaporated and the solid remaining recrystallized from hexane to yield $3.4 \mathrm{~g}(95 \%)$ of the ketone 8; m.p. $78-79 \mathrm{C}$; ${ }^{1} \mathrm{H}-\mathrm{NMR}\left(\mathrm{CDCl}_{3}\right) \quad \delta$ 7.94-7.74 (m, 8H, $\left.\mathrm{ArH}\right)$; 
MS $299\left(\mathrm{M}^{+}-80\right), 207\left(\mathrm{M}^{+}-172\right)$; i.r. $\left(\mathrm{cm}^{1}\right) 1667$, 1612, 1581, 1411, 1324. Anal. Calcd for $\mathrm{C}_{15} \mathrm{H}_{8} \mathrm{BrF}_{5} \mathrm{O}$ : C, 47.52; H, 2.13. Found: C, 47.52; H, 2.08.

${ }^{18}$ F]bis(4-Trifluoromethyl)benzophenone 9. Nocarrier-added tetrabutylammonium $\left[{ }^{18} \mathrm{~F}\right]$ fluoride was prepared by combining tetrabutylammonium hydroxide $(2 \mu \mathrm{mol})$ and aqueous $\left[{ }^{18} \mathrm{~F}\right]$ ffuoride and evaporating the water $\left(100^{\circ} \mathrm{C}, \mathrm{N}_{2}\right)$. Traces of water were removed by azeotropic distillation with acetonitrile, and the residue dissolved in dimethylsulfoxide $(200 \mu \mathrm{L})$. Bromobenzophenone $8(2 \mathrm{mg})$ was added, and the solution heated at $150^{\circ} \mathrm{C}$ for $20 \mathrm{~min}$. The mixture was cooled, diluted with water, and passed through a C-18 Sep-Pak. The solid phase was washed with water $(5 \mathrm{~mL})$ then the product eluted with diethylether $(2 \mathrm{~mL})$. Yields ranged from $20-75 \%$ with an average of $50 \%$. The product 9 was used in the next step without further purification. TLC System A) $R_{\mathrm{f}}=0.57$.

$(R, S)-\left[{ }^{18} F\right]$ bis-(4-Trifluoromethyl)benzhydrol 10. To a solution of ketone $9(100 \mu \mathrm{Ci}-5 \mathrm{mCi})$ in diethyl ether was added LAH $(200 \mu \mathrm{L}$ of $1 \mathrm{M}$ in THF $)$ and the solution allowed to stand at $25^{\circ} \mathrm{C}$ for $5 \mathrm{~min}$. Excess LAH was carefully quenched with water, $2 \mathrm{~N}$ $\mathrm{H}_{2} \mathrm{SO}_{4}$ added, and the mixture passed through a $\mathrm{C}-18$ Sep-Pak. The product was eluted with diethyl ether $(2 \mathrm{~mL})$ and then ether dried $\left(\mathrm{Na}_{2} \mathrm{SO}_{4}\right)$ to yield a solution of the desired alcohol 10 (yields $85-95 \%$ ). This was not further purified but used in the next step in the sequence. TLC (System A) $R_{\mathrm{f}}=0.2$.

$(R, S)-\Gamma^{18}$ Fbis(4-Trifluoromethyl)benzhydryl chloride (13). Chlorination of the alcohol $\mathbf{1 0}$ was done in dichloromethane solution (1-1.5 mL) using $100 \mu \mathrm{L}$ of phosphorus trichloride at $100^{\circ} \mathrm{C}$ (closed vessel). TLC showed complete chlorination after $35 \mathrm{~min}$. The solvent and excess $\mathrm{PCl}_{3}$ were removed by a slow stream of nitrogen, and the residue used in the next step without purification. TLC (System A) $R_{\mathrm{f}}=\mathbf{0 . 5 5}$

$(R, S)$-Ethyl I-[2-\{(4-IIS F]trifluoromethyl)phenyl $\}$ $\{(4$ trifluoromethyl)phenyl\}methoxyethyl $\}$-piperidine3-carboxylate 16. To the residue of chloride 13 was added ethyl $N$-(2-hydroxyethyl)-piperidine-3carboxylate $(10 \mathrm{mg})$, and the mixture heated at $155^{\circ} \mathrm{C}$ for $25 \mathrm{~min}$. The resultant brown oil was dissolved in methanol $(100 \mu \mathrm{L})$, diluted with water $(2 \mathrm{~mL})$ and extracted with diethyl ether. The ether layers were combined and dried $\left(\mathrm{Na}_{2} \mathrm{SO}_{4}\right)$ and the ether evaporated $\left(\mathrm{N}_{2}\right.$ flow). The residue was dissolved in dichloromethane and passed through a short column of silica gel to yield the desired crude product $\mathbf{1 6}$. Yield 33\%; TLC (System B) $R_{\mathrm{f}}=0.43$.

$(R, S)-$ Ethyl 1-[2-\{(4- $\left[{ }^{18} F\right]$ fluorophenyl)phenyl $\}$ meth oxyethyl]-piperidine-3-carboxylate (14). This condensation was performed as per synthesis of 16 , using the chloride 11; yield 49\%; TLC (System B) $R_{\mathrm{f}}=0.375$.

$(R, S)$-Ethyl-1-[2-(4-[ $\left.{ }^{18} F\right]$ fluorophenyl)(4-fluorophenyl)methoxyethyljpiperidine-3-carboxylate (15). This ester was prepared utilizing chloride 12 as per the synthesis of 14: yield 31\%. TLC (System B) $R_{\mathrm{f}}=0.28$; (System C) $R_{\mathrm{f}}=0.68$.
$(R, S)-1-\left[2-\left\{\left(4-\left[{ }^{18}\right.\right.\right.\right.$ F]Trifluoromethyl)phenyl $\}\{(4-$ trifluoromethyl)phenyl \}methoxyethyl]-piperidine-3carboxylic acid (3). The crude ethyl ester 16 was dissolved in 3 drops $6 \mathrm{~N} \mathrm{H}_{2} \mathrm{SO}_{4}$ and heated $\left(100^{\circ} \mathrm{C}\right)$ for $30 \mathrm{~min}$. The acid solution was diluted with $6 \mathrm{~mL}$ of $20 \mathrm{mM} \mathrm{K} \mathrm{HPO}_{3}$ buffer (pH 6.5) and extracted with two $2 \mathrm{~mL}$ portions of $4 / 1$ chloroform/isopropanol. The organic layers were combined, dried, and evaporated in vacuo. Yield $83 \%$, radiochemical purity $95 \%$; TLC (System C) $R_{\mathrm{f}}=0.42$; HPLC $R_{\mathrm{t}}=8.88 \mathrm{~min}$.

$(R, S)-1-\left[2-\left\{\left(4-{ }^{18} \mathrm{~F}\right]\right.\right.$ Fluorophenyl)phenyl $\}$ methoxyethyl]-piperidine-3-carboxylic acid (1). Hydrolysis of the ethyl ester 14 was done as per the synthesis of 3. Yield $90 \%$, radiochemical purity $97 \%$; TLC (System B) $R_{\mathrm{f}}=0.05$, (System C) $R_{\mathrm{f}}=0.35 ;$ HPLC $R_{\mathrm{t}}=6.83 \mathrm{~min}$.

$(R, S)-1-\left\{2-\left(4-\left[{ }^{18} F\right]\right.\right.$ Fluorophenyl)(4-fluorophenyl)methoxyethyl \}piperidine-3-carboxylic acid (2). Hydrolysis of the ester 15 was done as per synthesis of 3. Yield $85 \%$, radiochemical purity $96 \%$; TLC (System B) $R_{\mathrm{f}}=0.05$ : (System C) $R_{\mathrm{f}}=0.40 ;$ HPLC $R_{\mathrm{t}}=7.12 \mathrm{~min}$.

\section{Results and Discussion}

Preparation of radiolabeled inhibitors of the high affinity GABA uptake system would form a new and potentially powerful method for examining the distribution and function of this neurotransmitter system in vivo. GABA uptake sites show a heterogeneous distribution in primate brain, with a more than 4-fold difference between areas of low concentration (pons, deep cerebellar nuclei) and those of high concentration (amygdala, hypothalamus, globus pallidus) (Enna, 1981). Similarly, regional variations in $\left[{ }^{3} \mathrm{H}\right]$ nipecotic acid binding to GABA uptake sites in human brain tissue samples has been reported (Simpson et al., 1988).

Guvacine (1,2,5,6-tetrahydronicotinic acid) and nipecotic acid (3-piperidine-carboxylic acid) are potent in vitro inhibitors of GABA uptake into both neurons and glial cells, with no affinity for GABA receptors (Krogsgaard-Larsen et al., 1987). These amino acids, however, do not readily pass the blood-brain barrier (BBB) and thus are not good candidates for radiolabeling with ${ }^{11} \mathrm{C}$ or ${ }^{18} \mathrm{~F}$ ([1"C]GABA has been recently prepared (Antoni and Langstrom, 1989) but suffers the same in vivo limitation). Preparation of esters of such acids provides prodrugs which do pass through the BBB and are hydrolyzed in the brain to the active parent drugs (Frey et al., 1979; Falch et al., 1978). Application of prodrugs to PET imaging, although interesting, may be too complicated for successful analysis of in vivo pharmacokinetics. The placement of small alkyl groups on the nitrogen in guvacine or nipecotic acid has resulted in compounds which are less active than the parent amino acids, but surprisingly the attachment of large lipophilic groups, such as diarylbutenyl (Ali et al., 1985; Braestrup et al., 1990; Sonnewald, 
1987) or diarylmethoxyethyl groups, (Pavia, 1988; Falch and Krogsgaard-Larsen, 1989), provides compounds which are actually more active as GABA inhibitors ( $\mathrm{IC}_{50}$ values of $67-30 \mathrm{nM}$ ) than the parent amino acids, and do show potent in vivo activity after systemic administration. One such compound, NO 328 ((R)- $N$-[4,4-bis(3-methyl-2-thienyl)but-3-en-1yl]nipecotic acid), has been recently prepared in tritiated form and its in vitro and in vivo behavior examined in some detail (Braestrup et al., 1990). Their results $\left(K_{\mathrm{D}}=18 \mathrm{nM}\right.$, and regional variation in binding to brain synaptosomes) are encouraging for further development of radioligands for GABA uptake sites. As we have recently developed general routes to ${ }^{18} \mathrm{~F}$ labeled diarylmethanols $\left(4-\left[{ }^{18} \mathrm{~F}\right]\right.$ fluorobenzhydrol, Haka et al., 1989; 4- $\left(\left[{ }^{18} \mathrm{~F}\right]\right.$ fluorophenyl) (2-thienyl)methanol, Kilbourn, 1989; 4-[ ${ }^{18}$ F]fluoro-4' fluorobenzhydrol, Haka and Kilbourn, 1990), the application of such precursors to synthesis of ${ }^{18} \mathrm{~F}$ labeled derivatives of these cyclic amino acids appcarcd promising. A large number of substituted diphenylmethoxyethyl derivatives of nipecotic acid and guvacine have been recently reported (Pavia, 1988 ) and we chose to prepare fluoroaryl $(1,2)$ and trifluoromethyl (3) substituted diarylmethoxyethyl derivatives to test the feasibility of our synthetic approach. The reported $\mathrm{IC}_{50}$ for GABA uptake for compound 3 (as the $R(-)$ stereoisomer) is $200 \mathrm{nM}$ (Taylor and Vartanian, 1989); data for the other two compounds have not been reported. The $K_{\mathrm{D}}$ values, which for NO $328(18 \mathrm{nM})$ is significantly lower than the $\mathrm{IC}_{50}$ for GABA uptake $(67 \mathrm{nM})$, have also not yet been reported.

Synthesis of the target molecules was broken down into two parts, the preparation of the appropriately labeled benzhydryl chlorides $(\mathbf{1 1}, \mathbf{1 2}, \mathbf{1 3})$, followed by condensation with the ethyl ester of $N$-(2-hydroxyethyl)nipecotic acid. High specific activity $4-\left[{ }^{18} \mathrm{~F}\right]$ fluorobenzhydryl chloride (11) and 4- $\left[{ }^{18}\right.$ F ffluoro-4'-fluorobenzhydryl chloride (12) were prepared by minor modifications of previously described methods. The ${ }^{18} \mathrm{~F}$ labeled bis(trifluoromethyl)benzhydryl chloride (13) was prepared by the sequence shown in Fig. 2. Terephthaldehyde was<smiles>O=Cc1ccc(C=O)cc1</smiles>

Fig. 2. Synthesis of $\left[{ }^{18} \mathrm{~F}\right]$ bis(4-trifluoromethyl)benzhydryl chloride. 
fluorinated (DAST; 54\% yield) and the intermediate 4-difluoromethylbenzaldehyde (5) reacted with 4-trifluoromethylphenylmagnesium bromide to give the benzhydrol 6 in $80 \%$ yield. The alcohol was oxidized to the ketone $(7,74 \%$ yield) using Jones reagent under standard conditions. Bromination of the difluoromethyl group was performed using bromine in $\mathrm{CCl}_{4}$ under photolytic conditions ( $90 \%$ yield), with solid potassium carbonate added to consume $\mathrm{HBr}$ formed in the reaction. This bromodifluoromethyl group was then converted to a ${ }^{18} \mathrm{~F}$ labcled trifluoromethyl group by a simple reaction with no-carrier-added $\left[{ }^{18} \mathrm{~F}\right]$ fluoride ion (as salt with tetrabutylammonium, $\mathrm{K}^{+} / \mathrm{Kryptofix}$, or quaternary ammonium resin (Mulholland et al., 1989b) counterion) in $50 \%$ yield (average; $25 \mathrm{~min}$ reaction time). The ease of this synthesis of a $\left[{ }^{18} \mathrm{~F}\right]$ trifluoromethyl group was surprising since previous attempts at ${ }^{18} \mathrm{~F}$-for- ${ }^{19} \mathrm{~F}$ (Ido et al., 1987) or ${ }^{18} \mathrm{~F}$-for-Cl (Angelini et al., 1986) substitutions required high temperature and/or Lewis acid catalysts, and products were obtained in only moderate yields. The ketone 9 was then reduced (10: $\mathrm{LAH} ; 90 \%$ yield) and chlorinated $\left(\mathrm{PCl}_{3}\right.$ in $\mathrm{CH}_{2} \mathrm{Cl}_{2}$ or neat $\mathrm{SOCl}_{2} ; 95-100 \%$ yield) to give the required benzylic chloride 13 .
The benzhydryl chlorides $11,12,13$ were reacted with ( $N$-2-hydroxyethyl)nipecotic acid ethyl ester (Fig. 3) to yield the intermediate ethers $14,15,16$ in $33-49 \%$ yields. The products were separated from unreacted benzylic chlorides by extraction of the piperidine derivatives into dilute aqueous acid, and from excess $N$-hydroxynipecotic acid ester by a short column of silica gel. Finally, the ester groups were hydrolyzed under acidic conditions to yield the free amino acids 1,2,3. Products were obtained in high radiochemical purities ( $>95 \%$ by TLC and/or HPLC) but all contained trace amounts of chemical impurities. Small amounts of chemically pure products were obtained after injection of portions of the crude products on the analytical HPLC column. All of the final product acids 1,2 and 3 have been obtained as racemic mixtures (mixtures of isomers at the carboxylic acid position) and compound 1 as also a mixture of isomers at the benzylic position.

In this work we have demonstrated the feasibility of preparing $0.1-1.0 \mathrm{mCi}$ amounts of ${ }^{18} \mathrm{~F}$ labeled derivatives of compounds known to be systemically active as GABA uptake inhibitors. Overall radiochemical yields (5 steps from resolubilized $\left[{ }^{18} \mathrm{~F}\right]$ fluoride ion) ranged from $17-28 \%$ (corrected, $150 \mathrm{~min}$ synthesis

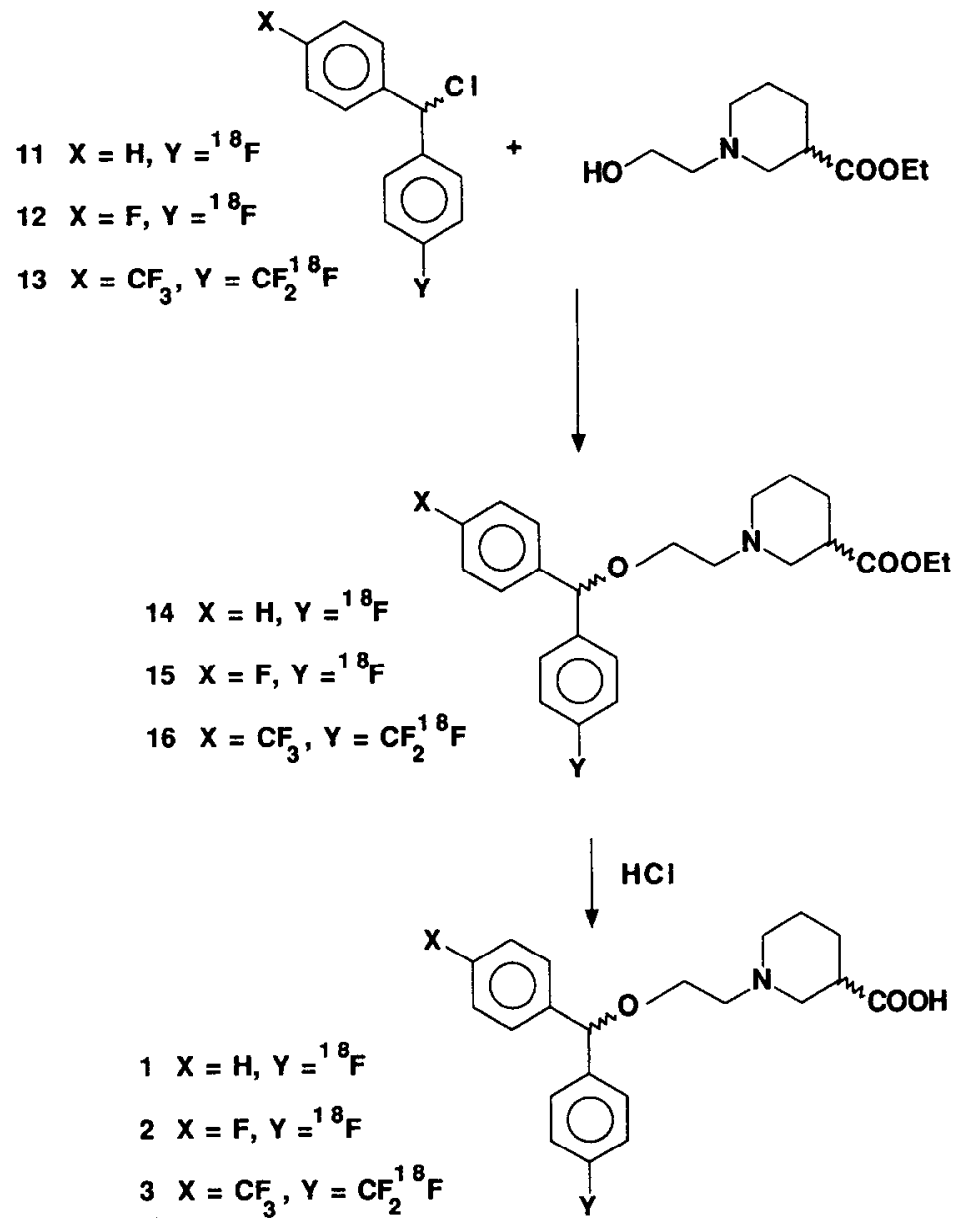

Fig. 3. Synthesis of ${ }^{18} \mathrm{~F}$ labeled GABA uptake inhibitors. 
time). The mono- and bisfluoro derivatives 1 and 2 have been obtained in high specific activity ( $>2000 \mathrm{Ci} / \mathrm{mmol}$ ). The bis(trifluoromethyl) substituted derivative, $\mathbf{3}$, has also been obtained in nocarrier-added form, but it requires a separation from small amounts of the compound bearing the original bromodifluoromethyl group; without this separation, the effective specific activity should be more properly described as lower (about $1 \mathrm{Ci} / \mathrm{mmol}$ ) as the chemical contaminant is likely to be biologically active. These specific activities have been sufficient to begin in vivo testing of the compounds in small animals. The effect of stereochemistry at the benzylic position in 1 is unknown, but the $\mathrm{R}(-)$ isomer of nipecotic acid and its derivatives are more potent inhibitors of GABA uptake (Pavia, 1988; Taylor and Vartanian, 1989). Syntheses of the $\mathrm{R}(-)$ isomers (carboxylic acid position) should provide better radiotracers, and are currently underway in our laboratories, as is the preparation of the corresponding guvacine derivatives (e.g. 1-\{2-\{bis(trifluoromethyl)phenyl $\}$ methoxy $\}$ ethyl)-1,2,5,6-tetrahydro-3-pyridine carboxylic acid, Cl-966: (Pavia, 1988; Brahce et al., 1989) and thienylsubstituted derivatives (Kilbourn, 1989). Preliminary in vivo studies of regional mouse brain distribution of 1 have been encouraging, with a cortex/striatum ratio (\% injected dose per gram) of $1.44+0.36$ at $1 \mathrm{~h}$ after injection; this compares favorably with the ratio of 1.53 for specific binding of $\left[{ }^{3} \mathrm{H}\right] \mathrm{NO} 328$ to rat brain synaptosomes determined in vitro (Braestrup et al., 1990). The availability of radiolabeled ligands will allow examination of in vivo characteristics of this class of compounds (brain extraction; regional distribution and specificity of radiotracer binding in brain; kinetics of radiotracer accumulation and washout from brain; pharmacological specificity of binding; neuronal vs glial specificity).

Acknowledgements - This work was supported by grants from the National Institutes of Health (NS 15655) and the Department of Energy (DE-AC02-76EV02031). The authors thank the cyclotron staff of the Division of Nuclear Medicine for carrying out the irradiations, Dr Michael Haka for assistance with the HPLC analyses, and Dr Anne Young for many stimulating discussions.

\section{References}

Ali F. E., Bondinell W. E., Dandridge P. A., Frazee J. S., Garvey E., Girard G. R., Kaiser K., Ku T. W., Lafferty J. J., Moosammy G. I., Oh H.-J., Rush J. A., Setler P. E., Stringer O. D.. Venslavsky J. W., Volpe B. W., Yunger L. M. and Zirkle C. L. (1985) Orally active and potent inhibitors of $\gamma$-aminobutyric acid uptake. $I$. Med. Chem 28, 653 .

Angelini G., Speranza M., Shiue C-Y, and Wolf A. P. (1986) $\mathrm{H}^{18} \mathrm{~F}+\mathrm{Sb}_{2} \mathrm{O}_{3}$. A new selective radiofluorinating agent J. Chem. Soc. Chem. Commun. 924.

Antoni G. and Langstrom B. (1989) Synthesis of $\gamma$ amino[4- ${ }^{11}$ ]butyric acid (GABA). J. Labeled Compd Radiopharm. 27, 571 .

Braestrup C., Nielsen E. B., Sonnewald U., Knutsen L. J. S. Andersen K. E., Jansen J. A., Frederiksen K., Andersen P. H., Mortensen A. and Suzdak P. D. (1990) (R)- $N-[4,4$ bis(3-methyl-2-thienyl)but-3-en-1-yl]nipecotic acid binds with high affinity to the brain $\gamma$-aminobutyric acid uptake carrier. J. Neurochem. 54, 639.

Brahce L. J., Schwarz R. D., Boyd D. K., Coughenour L. L. Pugsley T. A. and Clark C. R. (1989) Biochemical characterization of CI-966: a centrally active GABA uptake inhibitor. Soc. Neuroscience, 19lh Annual Meeting, 1989. Abstract 272.2.

Enna S. J. (1981) GABA receptor pharmacology: functional considerations. Biochem. Pharm. 30, 907

Falch E. and Krogsgaard-Larsen P. (1989) GABA uptakc inhibitors containing mono- and diarylmethoxyalkyl $N$-substituents. Drug. Des. Deliv. 4, 205.

Falch E., Meldrum B. S. and Krogsgaard-Larsen P. (1987) GABA uptake inhibitors. Synthesis and effects of audiogenic seizures of ester prodrugs of nipecotic acid, guvacine, and cis-4-hydroxynipecotic acid. Drug Des. Deliv 2, 9.

Frey H.-H., Popp C. and Loscher W. (1979) Influence of inhibitors of the high affinity GABA uptake system on seizure thresholds in mice. Neuropharm. 18, 581

Frost J. J., Wagner H. N. Jr, Dannals R. F., Ravert H. T., Wilson A. A., Links J. M., Rosenbaum A. E., Trifiletti R. R. and Snyder S. H. (1986) Imaging benzodiazepine receptors in man with "C-suriclone by positron emission tomography. Eur. J. Pharmacol. 122, 381.

Haka M. S. and Kilbourn M. R. (1990) Synthesis of $\left[{ }^{18}\right.$ F]GBR 12909 , a dopamine reuptake inhibitor. $J$. Labeled Compd. Radiopharm. In press.

Haka M. S., Kilbourn M. R., Watkins G. L. and Toorongian S. A. (1989) Aryl trimethylammonium trifluoromethanesulfonates as precursors to aryl $\left[{ }^{18} \mathrm{~F}\right]$ fluorides: improved synthesis of $\left[{ }^{18} \mathrm{~F}\right] \mathrm{GBR} 13119$. J. Labeled Compd. Radiopharm. 27, 823.

Ido T., Irie T. and Kasida T. (1987) Isotope exchange with ${ }^{18} \mathrm{~F}$ on superconjugate system. $J$. Labeled Compd. Radiopharm. 16, 153.

Kilbourn M. R. (1989) Thiophenes as phenyl bio-isosteres Application in radiopharmaceutical design I. Dopamine uptake antagonists. Nucl. Med. Biol. 16, 681

Krogsgaard-Larsen P., Falch E., Larsson O. M. and Schousboe A. (1987) GABA uptake inhibitors: relevance to antiepileptic drug research. Epilepsy Res. 1, 77.

Maziere M., Godot J. M., Berger G., Prenant C. and Comar D. (1980) High specific activity carbon-11 labeling of benzodiazepines: diazepam and flunitrazepam. $J$. Radioanal. Chem. 56, 229.

Maziere M., Hantraye Ph., Prenant C., Sastre J. and Comar D. (1984) Synthesis of ethyl 8-fluoro-5,6-dihydro-5 ("C)methyl-6-oxo-4H-imadazo( $1,5-\mathrm{a})(1,4)$ benzo-diazepine-3-carboxylate (RO $151788-" \mathrm{C}$ ), a specific radioligand for the in vivo study of central benzodiazepine receptors by positron emission tomography. Int. J. Appl. Radiat. Isot. 35, 973

Mulholland G. K., Hichwa R. D., Kilbourn M. R. and Moskwa J. (1989a) A reliable pressurized water target for F-18 production with high beam currents. J. Labeled Compd. Radiopharm. 26, 192.

Mulholland G. K., Magner T. J., Jewell D. M and Kilbourn M. R. (1989b) Polymer supported nucleophic radiolabeling reactions with $\left[{ }^{18} \mathrm{~F}\right]$ fluoride and [" $\mathrm{C}$ ]cyanide ion on quaternary ammonium resins. J. Labeled Compd. Radiopharm. 26, 378.

Pavia M., (1988) Various N-substituted 3-piperidine carboxylic acids or $\mathrm{N}$-substituted 3-pyridinecarboxylic acids and derivatives thereof. US Patent 4,772,615.

Simpson M. D. C., Cross A. J., Slater P. and Deakin J. F. W. (1988) Loss of cortical GABA uptake sites in Alzheimer's disease. J. Neural Trans. 71, 219.

Sonnewald U. (1987) Preparation of heterocyclylbutenylpyridylcarboxylates as $\gamma$-aminobutyric acid uptake inhibitors. European Patent 231,996.

Taylor C. P. and Vartanian M. G. (1989) Anticonvulsant and behavioral effects of CI-966 and PD 126141, potent GABA-uptake inhibitors, in animals. Soc. Neuroscience 19h Annual Meeting 1989. Abstract 272.3 